\title{
MEDICINSKA GEOGRAFIJA
}

\section{SAŽETAK}

\author{
Vesna KRALJ, dipl. ing., prof. mentor \\ Škola za medicinske sestre Vinogradska \\ Vinogradska cesta 29, 10000 Zagreb \\ vesna.kralj4@gmail.com
}

Medicinska geografija suvremena je znanstvena disciplina koja primjenjuje metodologiju geografije, te koristi tehnike i koncepte svih disciplina geografije pri istraživanju zdravstvenih problema u prostoru, proučava $\mathrm{i}$ geografsku rasprostranjenost oboljenja, te aktualne novonastale zdravstvene probleme i bolesti. U sklopu geografije slijedi se stoljetni cilj - razmatranje veze prostor - geografski okoliš - zdravlje. Korijeni joj sežu u daleku povijest. Najpoznatiji dokaz je citat Hipokrata, 400 godina prije Krista. O zraku, vodama i mjestima gdje Hipokrat ukazuje na povezanost okoliša i kulturnih običaja za zdravljem ljudi. Liječnici iz 18. i 19. stoljeća prvi su upotrijebili pojam „medicinska geografija“ i nastojali u svojim djelima opisati i organizirati mnoge nove informacije u kojima se uočava povezanost bolesti, kultura i okoliša, te su tako nastavljali holističku Hipokratovu tradiciju. Ovdje ističemo istaknute znanstvenike koji su utemeljili medicinsku geografiju. To su Jacques Mayer May i Leonhard Ludwig Finke. Finke je namjeravao „stvoriti“ geografsko-povijesno-sociološki“ esej i tiskane karte koje bi bile prve karte svjetskih bolesti. Medicinska geografija je ipak suvremena znanost, čiji početak počinje iza 1950. godine. Primjena metodologije geografije za proučavanje zdravlja, znanosti napreduje koristeći razne teorije, pristupe, interese i metodologije. Ujedno sudjeluje u brojnim projektima, te ih i stvara. Utemeljitelj „otac“ suvremene medicinske geografije, je Jacques Meyer May (1896. - 1976.), francuski liječnik kirurgije. On smatra da je medicinska geografija proučavanje o vezi između patoloških faktora koji je mogu zvati „patogeni“ i geografskih faktora koje je dr. May nazvao, „geogeni“. Kartiranje (mapiranje) zdravstvenih problema, odnosno unošenje medicinskih podataka na geografske karte danas je redovita pojava. Prema tematskom području karte sa medicinskim sadržajem su geomedicinske karte. Medicinska geologija je suvremena znanstvena disciplina u progresiji koja se bavi proučavanjem utjecaja geoloških materijala i procesa na zdravlje ljudi, kao i na životinje i biljke, pri čemu se uočavaju dobri i mogući opasni utjecaji. Elementi u tragovima, bitni za naše zdravlje posredno ili neposredno potječu iz Zemljine kore. Biometeorologija odnosi se na sponu vrijeme - klima zdravlje.

Ključne riječi: Medicinska geografija, prostor-zdravlje, L. L. Finke, kartiranje bolesti, J. M. May, patogeni geogeni.

MEDICINSKA

GEOGRAFIJA:

znanstvena disciplina socijalne geografije

Geografija, znanost o geografskom prostoru, kompleksna je s obzirom na sadržaj proučavanja. Zbog složenosti geografskog prostora ona objašnjava prostor povezujući prirodne i društvene znanosti. Zato se i kaže za geografiju da je dualna znanost iako, temeljno prirodna. Sintetička je interdisciplinarna znanost sa jasno definiranom metodologijom. S 
obzirom na složenost prostora sastoji se od većeg broja geografskih disciplina koje imaju svoje zasebne ciljeve i sadržaje proučavanja. Geografske discipline koje su nam poznate kroz nastavno gradivo su na primjer geomorfologija, klimatologija, hidrogeografija, ili društvene urbana geografija, ekonomska, politička, historijska. S obzirom na interdisciplinarnost može je se vezati na više znanosti i područja. Rad u medicinskoj školi potaknuo me na proučavanje sadržaja u kojima je geografija u sponi sa zdravljem i problemima vezanim za zdravstvenu djelatnost. S vremenom se dakle, izdvojila posebna grana koja povezuje zdravlje ljudi $\mathrm{i}$ prostor. Radeći sa učenicima $\mathrm{u}$ medicinskoj školi učinilo mi se interesantno i važno upoznati učenike sa geografskom disciplinom geografije koja se zove medicinska geografija. U mnogim temama geografije uočava se veza (korelacija) Zemlje, ljudi i društvenih aktivnosti sa zdravljem. U medicinskoj geografiji posebno je važna prostorna rasprostranjenost pojedinih bolesti, kao što je sada aktualna pandemija koronavirusa, koja se munjevitom brzinom u uvjetima današnje tehnologije i kretanja ljudi, proširila cijelom planetom, odmah se postavilo pitanje izvorišta bolesti, okolnosti i slično, a sada je aktualno pitanje distribucije cjepiva, ali i odnos ljudi prema njima što ima veze sa kulturološkim čimbenicima i općem obrazovanju stanovništva. Pojave bolesti se prate globalno, regionalno i lokalno, sagledavaju se prostorne okolnosti, traži se uzrok i rješenje novonastalog zdravstvenog problema. Brojni su primjeri i sadržaji koji mogu biti i jesu predmet proučavanja medicinske geografije, od prehrane i prehrambenih sastojaka koji su prisutni u više ili manje dovoljnim količinama i kvaliteti u pojedinim zemljama i regijama. Često istražujemo geografsko porijeklo ljekovite biljke, a ljekarne obiluju lijekovima kojima ističu prirodno porijeklo. Minerali koji imaju porijeklo i u Zemljinoj kori. Kvaliteta vode, ljekovite vode, klima i vremenske pojave odražavaju se na naše zdravlje i kvalitetu života. Sve to ukazuje na važnost suvremene znanstvene grane - medicinske geografije čiji korijeni sežu daleko u povijest. Međuzavisnost prostora i njegovih prirodnih i društvenih karakteristika, te zdravlja odavno je uočena (Meade, Earickson, 2005).

\section{ZAŠTO JE VAŽNA MEDICINSKA GEOGRAFIJA}

Medicinska geografija suvremena je znanstvena disciplina, starih korijenova, koja danas primjenjuje metodologiju 
geografije, te koristi tehnike i koncepte svih disciplina geografije pri istraživanju zdravstvenih problema u prostoru. Ujedno proučava i geografsku rasprostranjenost oboljenja, te aktualne novonastale zdravstvene probleme i bolesti. Interdisciplinarna je subdisciplina koja koristi činjenice i tehnike $\mathrm{i}$ drugih različitih društvenih i prirodnih znanosti. $\mathrm{S}$ time $\mathrm{u}$ vezi pomaže traženju uzroka bolesti vezanih za prostor, zato može doprinijeti rješavanju različitih zdravstvenih problema. Geografi su uočili da zdravstveni fenomeni imaju određenu prostornu distribuciju, kreću se u određenim pravcima sa promjenjivom brzinom, utjeću na naselja i općenito okoliš. Primjeri su pojave novih bolesti u izmjenjenom okolišu, kao i njihovih prijenosnika, pri čemu je ključno pitanje lokacije njihovog žarišta. Na primjer, ebola koja se širila iz ekvatorijalne Afrike, te nedugo zatim mikrocefalija - ZIKA, (prijenosnik je tigrasti komarac) iz Afrike i Južne Amerike. Sada je aktualna pandemija koronavirusa i pojavom bolesti odmah se istraživalo geografsko izvorište, te širenje $\mathrm{u}$ prostoru. $\mathrm{S}$ time $\mathrm{u}$ vezi $\mathrm{i}$ preventivne mjere, ponajprije kretanje $\mathrm{s}$ kojim smo se suočili. Promjene na globalnoj razini, život u gradovima, nove tehnologije koje genetski mjenjaju hranu i bolesti, i brojni drugi primjeri.
Globalizacija koje je osobito uzela maha od kraja 20. stoljeća donosi brojne pozitivne i negativne posljedice. Brzo dostupne informacije, mogu brzo transportirati lijekove te zaustaviti širenje pandenija bolesti, ali kretanja stanovništva kako turistička tako i različita druga mogu utjecati i na lako širenje zdravstvenih problema. To sve geografima daje mnogo prostora za djelovanje. Geografi postavljaju cilj, koji uključuje prostor i holistički pristup razumijevanju zdravlja različitim aktivnostima, kao što su istraživanja ali i javnim izlaganjem, te pokušavaju doprinijeti unaprjeđenju zdravlja. Medicinska geografija u suradnji s dugim granama poput, na primjer, sociologije itd., iz geografske perspektive može pridonijeti zaštiti zdravlja. Usto, epidemiologija, mikrobiologija i srodne grane mogu biti sintetizirane i korištene za objašnjavanje prostorne distribucije pojave bolesti. Od 70-ih godina 20. stoljeća medicinski geografi su bolje educirani u srodnim područjima njihovih specijalizacija. Medicinska geografija je kompleksna jer može biti uključena $u$ brojna istraživanja, razmatrati pojave korištenjem zdravstvenih statističkih podataka te donositi nove ideje. Radi veće sigurnosti većina medicinskih geografa odlučuje se za rad na jednoj geografskoj disciplini (Meade, Earickson, 2005). 


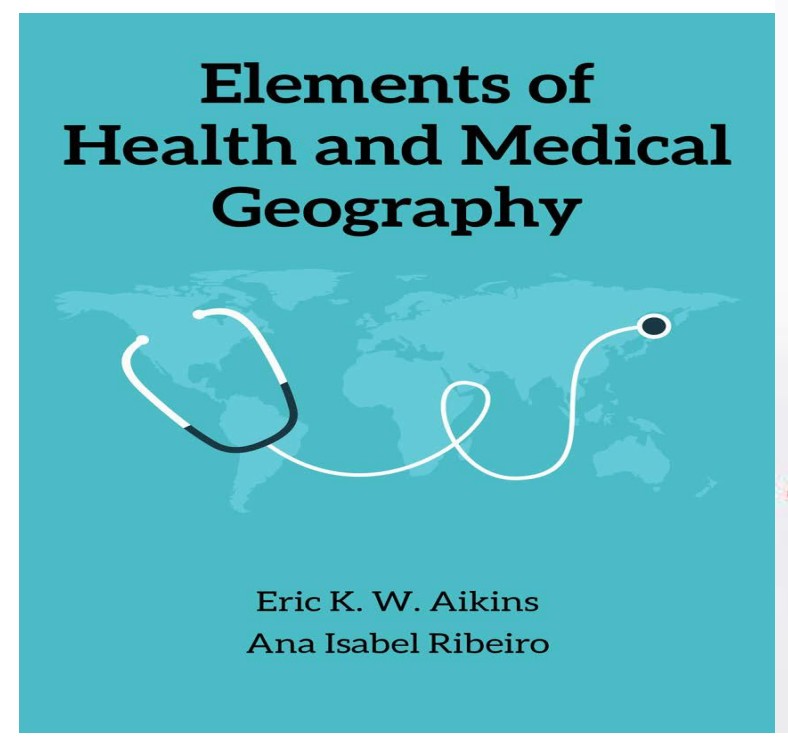

\section{A COMPANION TO \\ HEALTH AND \\ MEDICAL \\ GEOGRAPHY}

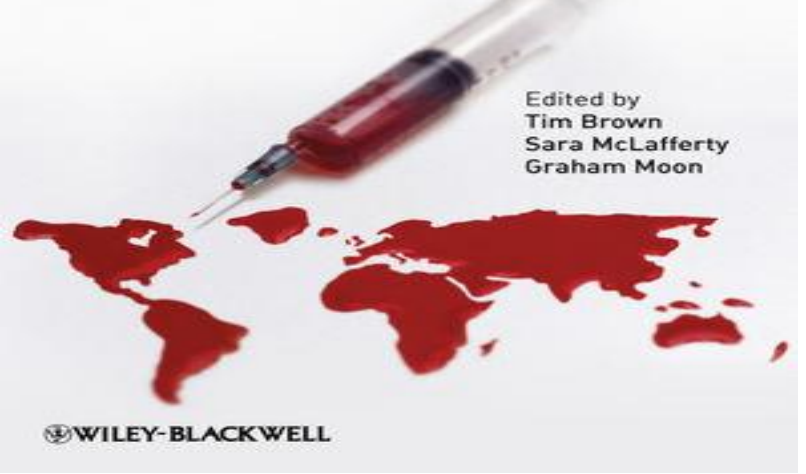

Slika 1. Slika prikazuje dva od više udžbenika na temu medicinske geografije, koja postaje jedno od važnih sestrinskih područja, gdje se objašnjava rasprostranjenost zdravlja i bolesti u vezi sa prirodnim i društvenim okolišem

\section{Prostor - geografski okoliš - zdravlje: koja pitanja postavljaju geografi}

U sklopu geografije slijedi se stoljetni cilj

- povezivanje svih fenomena sa naglaskom na prostor s namjerom da razumiju prirodu mjesta i objašnjavanje rasprostranjenosti različitih zdravstvenih fenomena $\mathrm{u}$ prostoru. Na taj način geografi su počeli razmatrati vezu prostor - geografski okoliš - zdravlje. Nekoliko ključnih pitanja se nastoji odgovoriti:

1. Zašto su pojedine promatrane bolesti mnoge češće u nekim mjestima, u nekima ne? (primjer - zarazne bolesti u tropskim klimama)

2. Zašto su neke bolesti mnogo rasprostranjenije u nekim kulturama, a u drugima ne?
3. Zašto se bolesti događaju nekim ljudima, a drugima ne? (dostupnost zdravstvenim uslugama, obrazovanje)

4. Kako i zašto se bolesti šire od mjesta do mjesta? (migracije...)

5. Kako može znanost kao što je geografija pomoći pojedincima, područjima i društvenim zajednicama održati dobro zdravlje? (traženjem uzroka u prostoru reljef, klima, voda, higijena, razvoj poljoprivrede...)

Znanost je dobila na zrelosti, medicinski geografi su prepoznati kao važni za različite projekte, što je rezultiralo 
zanimanjem za medicinsku geografiju (Misra, 2007).

\section{RAZVOJ DISCIPLINE}

\section{Od Hipokrata do suvremene znanstvene discipline}

Medicinska geografija, mlada je grana, koja se kao dobro definirana disciplina razvija posljednjih nekoliko desetljeća. Ipak korijeni joj sežu u daleku povijest. Najpoznatiji dokaz je citat Hipokrata, 400 godina prije Krista. O zraku, vodama i mjestima gdje Hipokrat ukazuje na povezanost okoliša i kulturnih običaja za zdravljem ljudi. Svijest o ekološkoj sponi bolesti i zdravlja kontinuirano se pojavljivala stoljećima sve do pojave prvih teorija u drugoj polovici 19. stoljeća. Liječnici iz 18. i 19. stoljeća prvi su upotrijebili pojam ,medicinska geografija“ i nastojali u mnogim svojim djelima opisati i organizirati mnoštvo novih informacija u kojima se uočava povezanost bolesti, kultura i okoliša, te su tako nastavljali holističku Hipokratovu tradiciju. Neki od znanstvenika koji su proučavali medicinsku geografiju su Finke, 18. st., Jacques Mayer May, 20. st. koje ćemo izdvojiti radi njihovog značenja, te mnog i drugi.
Leonhard Ludwig Finke, dr. medicine (1747. - 1837.), rođen u Westkappelnu, u Njemačkoj, jedan je od pionira medicinske geografije. Bavio se porodništvom, davao je savjete primaljama. Bio je i profesor medicine i fizike u Lingenu u Njemačkoj. Interes za medicinsku geografiju proizlazio je iz njegove profesionalne prakse. Kao medicinar posječivao je gradove i obližnja sela, ispitivao je izvore mineralnih voda, kupaone u domaćinstvima, promatrao kako primalje pružaju medicinsku skrb stanovništvu pri čemu se protivio šarlatanstvu. Zadatak mu je bio podnositi izviješča za pojedina upravna područja, što je uključivalo procjenu uvjeta okoliša, zdravstvenih uvjeta i života pojedinaca. To ga potaklo da proučava sadržaje medicinske geografije. Proučio je brojna djela, od kojih su neka imala presudan utjecaj na njega. Najprije Hipokratov zapis O zraku, vodi $i$ geografskim regijama. Finke je shvatio da je jedino Hipokratovo djelo nešto što se može smatrati medicinskom geografijom, a po njegovu mišljenju nijedno slično djelo unazad 2000 godina, od Hipokrata do njega nije napisano. Prema Finkeovoj definiciji medicinska geografija treba pokriti cijeli naseljeni svijet(ekumenu), stav koji nitko prije njega nije imao. Službeno je predstavio svoje ideje o medicinskoj geografiji u nastupnom predavanju kada je 
promoviran za profesora. Svoje je učenje objavio $\mathrm{i}$ istaknuo ne povezuje se jasno veza između uzroka i posljedice. Prostor je opustošen(pogođen) nekom bolesti, a ne može se shvatiti uzrok. S toga se usmjerio $\mathrm{s}$ opisnog prema uzročnom pristupu medicinskoj geografiji. Kao liječnik nadao se da će geografija moći ponuditi objašnjenja uzroka i učinka te pomoći

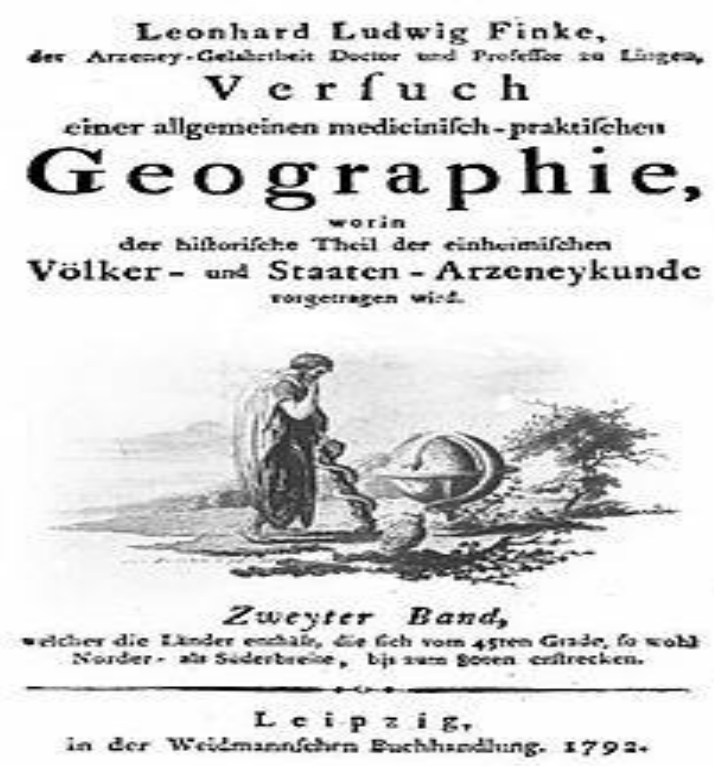

Najsveobuhvatnije je njegovo znanstveno djelo na temu medicinske geografije tog razdoblja, objavljeno 1792. je Opći pregled medicinsko-praktične geografije (Versuch einer allgemeinen medicinisch-praktischen Geographie. U tom kapitalnom djelu Finke ima geografski pristup, dijeli globus po dužini, te objašnjava prirodno-geografska obilježja svakog područja, znači, reljef, boljem razumijevanju bolesti. Godine 1789. prvi je predložio studij medicinske geografije svijeta. Tada je namjeravao „stvoriti“ geografsko-povijesnosociološki“" esej i tiskane karte koje bi bile prve karte svjetskih bolesti, ali nije imao podršku povjesničara, kartografa i geografa.

Slika 2. Slika prikazuje prvi udžbenika medicinske geografije, koji je izradio L. L. Finke 1792.

vode, tlo, vegetaciju te društvenogeografska obilježja kao što su način života stanovništva i slično. Iza tih klasičnih geografskih uvoda, kombiniraju se geografska i medicinska promatranja usmjeravajući saznanja prema liječnicima opće medicine što je smatrao svojom glavnom zadaćom. Radi brzog napretka geografije $u$ to vrijeme neke njegove 
informacije su brzo zastarijevale. Kvaliteta i vrijednost rada Finkea očituje se ne samo u prikupljanju i sistematizaciji nego ima značenje iznesenih činjenica i zapažanja pri čemu je on objasnio u detalje svoje konceptualno razumijevanje medicinske geografije. Zato njegov rad opravdano možemo smatrati geografskim, koji je temelj za definiranje medicinske geografije te osnova za daljnje istraživanje i razvoj. Budući da nije bio dovoljno prevođen $\mathrm{s}$ njemačkog na druge jezike, nije mu dano na vrijeme adekvatno značenje u razvoju medicinske geografije.

\section{MEDICINSKA GEOGRAFIJA NOVA ZNANOST}

Opise i istraživanja brojnih starijih prethodnika znanstvenici ponovno otkrivaju u 20. stoljeću. Na primjer, Frank Barrett od 1980. bavi se istraživanjem korijena medicinske geografije iz 19. stoljeća, objašnjavanjem širenja bolesti kao i početkom mapiranja bolesti. Začetak suvremene znanosti medicinske geografije te primjena metodologije geografije za proučavanje zdravlja, bolesti i njege traje već 60-ak godina. Suvremeni razvoj znanosti medicinske geografije veže se za Izvještaj Komisije o medicinskoj geografiji zdravlja i bolesti, koji je predan Međunarodnoj geografskoj uniji 1952. godine. To je povijesni dokument novog početka. Tek nakon 15-ak godina rad pionira istražitelja urodio je značajnim zanimanjem za medicinsku geografiju u međunarodnoj zajednici. Razvoj znanosti napreduje koristeći se raznim teorijama, pristupima, interesima i metodologijama (Finke, 2001; Meade, Earickson, 2005).

\section{Jacques Meyer May - „otac“ suvremene medicinske geografije}

Jacques M. May (1896. - 1976.), francuski liječnik kirurgije, smatra se „ocem“ novije povijesti medicinske geografije iz SAD-a, inicirao je medicinsku geografiju kao subdisciplinu 1950. - 1954. Najznačajnije mu je djelo Ekologija bolesti 1958. godine. Radio je kao kirurg u Tajlandu te niz godina $\mathrm{u}$ francuskoj bolnici u Hanoju. Interes za medicinsku geografiju počeo je pitajući se zašto pacijenti u tropskom podneblju pri tipičnim bolestima reagiraju različito na operacije i zdravstvenu njegu nego pacijenti u Europi. U tom području rad je nastavio proučavajući i liječeći brojne infekcije te sagledao uvjete života koji su uvjetovali i limitirali njihovo zdravlje i bolesti. Iako je svjestan spoznaja o okolišu u okviru epidemiologije ili parazitologije te se čini da nema ništa što već nije upoznato $\mathrm{u}$ pojedinim granama medicine, postavlja si pitanje koje bi bilo značenje medicinske geografije ili geografije zdravlja. 

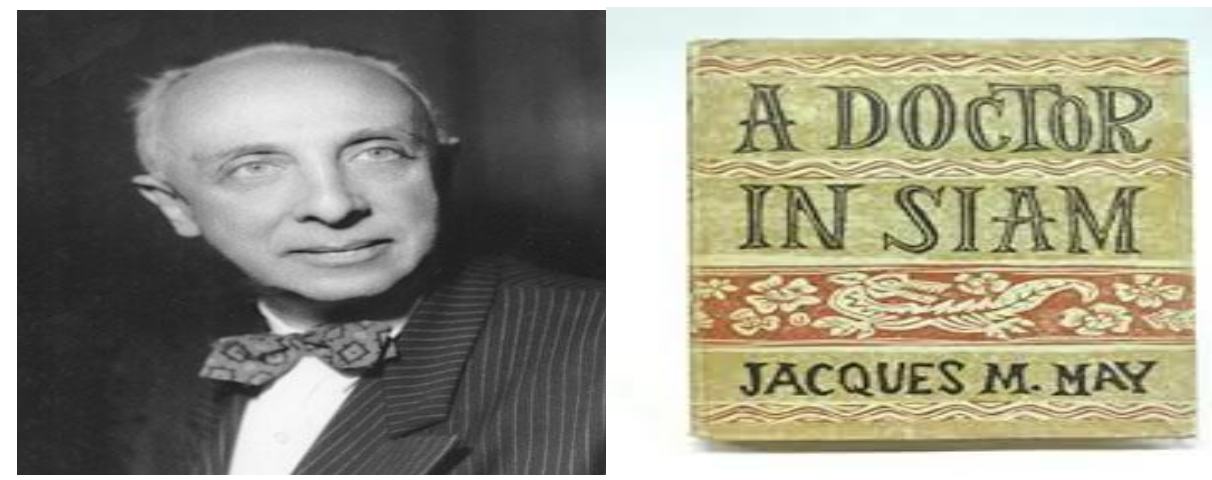

Slika 3. Dr. Jacques Meyer May, francuski kirurg, „otac“ medicinske geografije, smatra se začetnikom suvremene geografije. Radio je kao kirurg u Tajlandu i Vijetnamu, u svojim radovima pridavao je veliko značenje ekologiji bolesti te pomogao razvoju medicinske geografije kao poddiscipline. Izvor fotografija: Les Francias Libres (1940. - 1943.)

\section{Patogeni i geogeni - poveznica bolesti i prostora Zemlje}

Mnogo godina pažnja liječnika bila je usmjerena na simptome bolesti. Kasnije sa napretkom kemije i fizike, pažnja je usmjerena na biokemijske poremećaje koji rezultiraju bolestima. Pristup postaje sve dublji i istražuje se sve više ispod površine. Danas je prepoznato da je bolest mnogostruki fenomen koji se događa samo ako se različiti faktori isprepletu $u$ vremenu i prostoru. Fokus interesa širi se od sadržaja koji je veza između različitih faktora ovog kompleksa i ,respektabilnog““ geografskog okoliša. To možemo nazvati predmetom interesa (istraživanja) medicinske geografije. Medicinska geografija je proučavanje o vezi između patoloških faktora koji je mogu zvati „patogeni“ i geografskih faktora koje je dr. May nazvao, „geogeni“. Dakle, konceptualni i metodološki okvir suvremene medicinske geografije počinje 1950. s publiciranim sadržajem J. M. May, Medicinska geografija: Metode i „objekti“ u časopisu The Geographical Review 1950. Poslije toga gotovo svi ,pisci“ slijede paradigmu ,geogens“ i ,pathogens“ te do danas mnogi medicinski geografi smatraju J. M. May povijesnom posebnošću na tom polju. Ipak, spominje se kao moguća preteča M. Sorre - jedan od najvećih geografa poslije Ratzela, prvi je ukomponirao biološke sadržaje u geografiju. Također je uspostavio vezu između geografije, medicine i sociologije. Formalni studijski program medicinske geografije prvi puta je uveden na američka sveučilišta od 1970-e. Danas se ističe nekoliko novih znanstvenika medicinske geografije, jedan od primjera je M. S. Meade, prva doktorica znanosti medicinske geografije (Brown, Moon 2004). 


\section{KARTIRANJE BOLESTI}

\section{Metoda geografije u medicinskoj geografiji}

Danas je gotovo uobičajeno da se pojava epidemije ili pandemije neke bolesti poput malarije, HIV-a, ebole, i danas COVID-19, te drugih predoči na tematskoj karti. Liječnici su odavno uočili velike mogućnosti kartografije i njene primjene $u$ zdravstvu, prostornoj analizi i predočavanju aktualnih podataka. Zato je to danas jedna od istaknutih metoda geografije $u$ medicinu i predočavanju bolesti. Danas je kartografija napredovala, razvila se digitalna kartografija i GIS. Oprez i umijeće predočavanja podataka na karte su potrebni radi mogućnosti pogreške i nepravilne predodžbe. Kartografski se predočava rasprostranjenosti i širenja pojedinih bolesti. Najčešće se prikazuju zarazne bolesti. Krajem 18. i početkom 19. stoljeća izrađene su prve karte epidemije žute groznice i kolere. Uočeno je da precizne geomedicinske karte mogu pomoći $u$ istraživanju uzroka ili izvora određene bolesti.
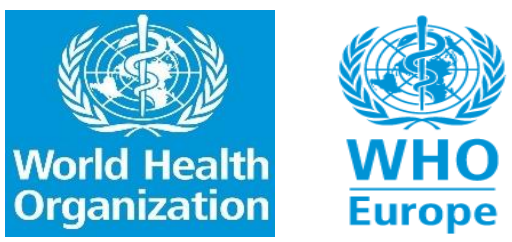

Slika 4. Na slici vidimo logo Svjetske zdravstvene organizacije, osnovane 1948., prvi predsjednik je bio dr. Andrija Štampar. Ona je ključni izvor najnovijih podataka vezanih za zdravlje na svjetskoj razini, momentalno vezano za koronavirus, podatci se koriste između ostalog za izradu tematskih geomedicinskih karata.

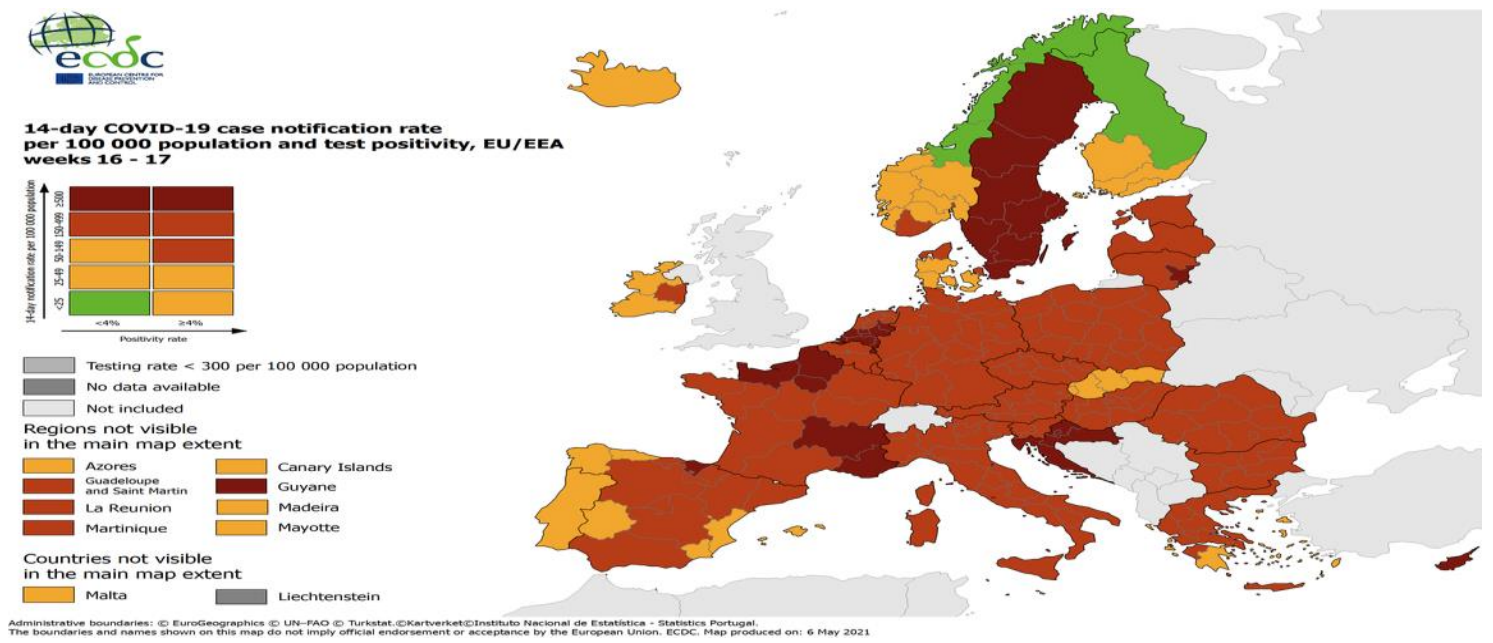

Karta 1. Karta prikazuje kombinirani pokazatelj: stopa obavijesti od 14 dana, stopa testiranja i pozitivnost ispitivanja, ažurirana 6. svibnja 2021 // ECDC ove karte objavljuje svakog četvrtka. Karte se temelje na 


\section{Kralj, Medicinska geografija}

podacima koje su države članice EU izvijestile u bazu podataka Europskog nadzornog sustava (TESSy) do 23:59 svakog utorka. IZVOR: European Centre for Disease Prevention and Control (ECDC) (Europski centar za prevenciju i kontrolu bolesti) Agencija Europske unije

Područja su označena bojama: najniža razina testiranosti i pozitivnosti označena je zelenom bojim, zatim povećanje se

\section{TEMATSKE KARTE}

$\mathrm{Za}$ istraživanje prostornih pojava i procesa koriste se često tematske karte. Tematske karte su karte na kojima se na temeljnoj karti unosi tematski sadržaj jedne ili više posebno istaknute teme $\mathrm{s}$ posebnom važnošću ili interesom. Prikazuju se sadržaji prirodnog, gospodarskog, društvenog i kulturnog prostora. Velik broj tema, raznolikost metoda kartografskog prikaza i vrlo raznolika namjena rezultira raznovrsnošću. U primjeni tematskih kartama našao je svoje mjesto i medicinski sadržaj koji je redovitom pristan i koristi metodu kartiranja.

Vizualizacija prostornih podataka je značajan element predočavanja na tematskim kartama, jasnoća prezentiranog sadržaja na preglednim kartama omogućuje jednostavno i zorno iščitavanje karata za široku populaciju, te kod izvornih preciznih istraživačkih karata lakše je uočavanje i istraživanje problema. prikazuje narančastom, crvenom, tamno crvenom i nedovoljan broj pokazatelja sivom bojim.

Vizualizaciju prostornih podataka i njihovih tema omogućuju brojna sredstva kartografskog izražavanja. Prema tematskom području karte s medicinskim sadržajem su geomedicinske karte (Lukić, 2003).

Novo doba u kartografiji općenito, pa tako i izradi tematskih karata počinje od 1980. naovamo, kada uz internet, mobilne komunikacije i slično dolazi do razvoja digitalne kartografije koja podrazumijeva primjenu računala u digitalnoj kartografiji, pojavljuje se i GIS, interaktivnost i „nova“ komunikacija između čovjeka i računala. Iza 2000. godine razvija se intenzivno multimedijska kartografija, internetske karte, moguće je stalno ažuriranje karata. Termin „tematske karte“ upotrijebio je 1934. godine Schumacher, a opće prihvaćen je poslije Drugoga svjetskog rata. 
Nastavnička revija 2 (2021) 1, 21-46

\section{Global Vaccine Timeline \\ Stretches to 2023}

Countries by when they are expected to have vaccinated

$60-70 \%$ of their adult population against COVID-19
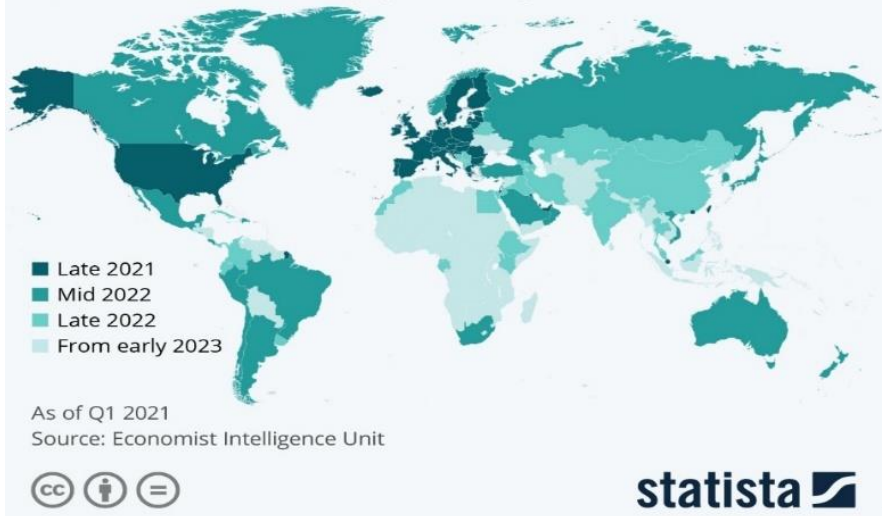

ist Intelligence Unit

Karta 2. Karta prikazuje očekivanost cijepljenosti

za COVID-19, država svijeta do 2023. godine (svibanj 2021.)

\section{COVID-19 vaccination rates}

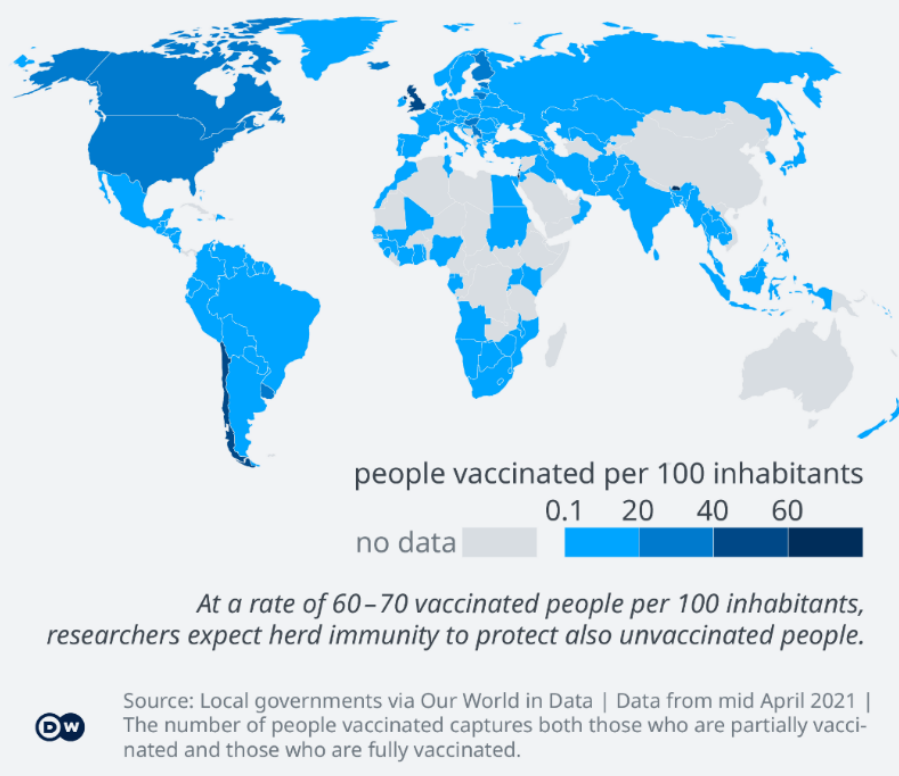

cijepljen na svakih 100 stanovnika (svibanj 2021.)
Karta 3. Karta prikazuje udio stanovnika 


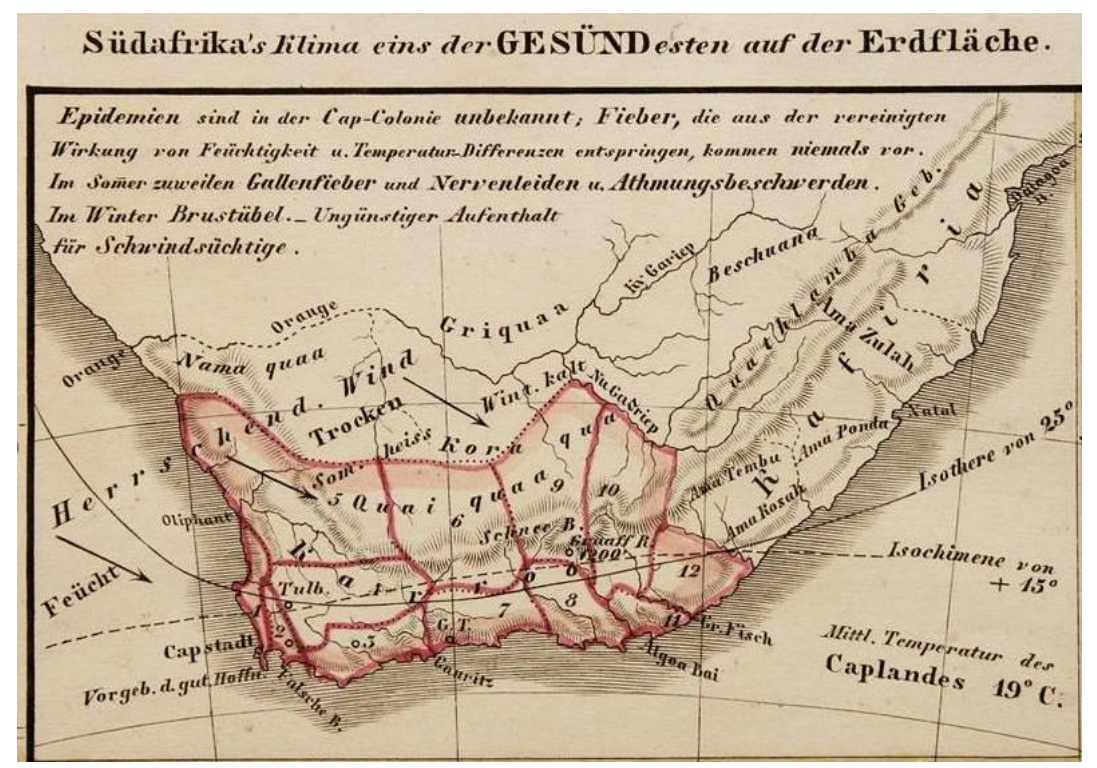

Karta 4. Karta južne Afrike podrobno objašnjava kvalitetu južnoafričke klime kao jedne od najzdravijih na Zemlji koja ne pogoduje širenju zaraznih bolesti koje obično nastaju iz uzajamnog djelovanja vlage i temperaturnih razlika - Izvor - Physical Atlas 1852., Dr. Heinrich Berghaus

Jedna od najpoznatijih karata bolesti potječe iz Engleske gdje je 1854. godine liječnik John Snow uspješno kartirao domaćinstva koja je zahvatila kolera. Ta karta s točkicama oko Broad Street u četvrti Soho u Londonu bila je ključ analize širenja zaraze. Pomoću karte dr. Snow ubrzo je uočio da je izvor bolesti voda obližnjeg bunara koji je zatim zatvoren, a širenje bolesti postepeno je zaustavljeno.
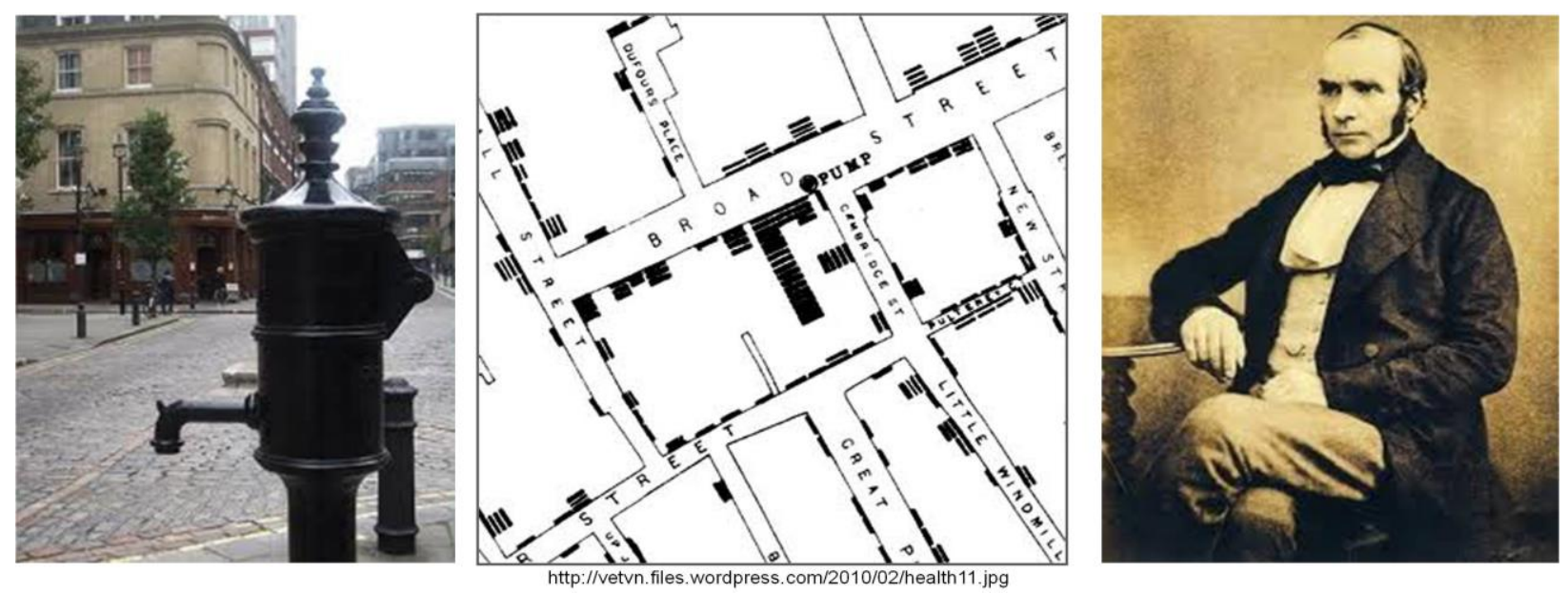

Slika 5. Karta (u sredini) liječnika John Snow iz Londona iz 1854. smatra se jednom od prvih najuspješnijih karta sa zdravstvenim sadržajem čija je analiza pomogla u rješavanju zdravstvenog problema - širenja zaraze kolere; desno: pumpa izvor zaraze; lijevo: dr. Snow 
Suvremena kartografija omogućava sustavno i pregledno predočavanje brojnih podataka. Počeci mapiranja u SAD-u, važni za razvoj medicinske geografije, potječu od Jacques May, kirurga, koji je napravio projekt mapiranja vektora, parazita i bolesti povezane s prehranom na svjetskoj razini za Američko geografsko društvo u New Yorku. Između 1950. i 1954. izradio je seriju od 17 karata koje su objavljene uz kratko objašnjenje za časopis The Geographic Review. Usto je objavljeno još nekoliko karata, pri čemu je pažnja većine geografa usmjerena na povezivanje rasprostranjenosti bolesti $\mathrm{u}$ sponi sa ekološkim i fizičkim okolišem i kulturnim obilježjima. Nakon nekoliko godina Rodenwaldt i Jusatz(1952-1961) izdali su mnogo iscrpniji, od tri dijela sastavljen Atlas svijeta epidemijskih bolesti (World Atlas of Epidemic Disease). Atlas se sastoji od globalnih i regionalnih karata, s posebnim naglaskom na prostor
Europe, te je popraćen komentarima o bolestima.KARTE BOLESTI I ZDRAVSTVENIH USLUGA NA LOKALNOJ, REGIONALNOJ, NACIONALNOJ, EUROPSKOJ I GLOBALNOJ RAZINI

Tematske karte imaju različite namjene i ciljeve, uvijek ističu jednu temu od posebne važnosti. Zato je uvijek važan prostorni obuhvat lokacije koja je od posebnog interesa pojedinačne tematske karte. Ovdje se radi o veličini prostora, te je mjerilo karte bitan element svake tematske karte. Karte velikog mjerila predočavaju manje prostore te možemo govoriti o sadržaju karte na lokalnoj razini. $\mathrm{Tu}$ su često i precizne znanstvenoistraživačke karte. S povećanjem prostora, odnosno, ako se izrađuju karte veće regije, države, kontinenta ili svijeta mjerilo se postepeno smanjuje, karta je uglavnom pregledna.

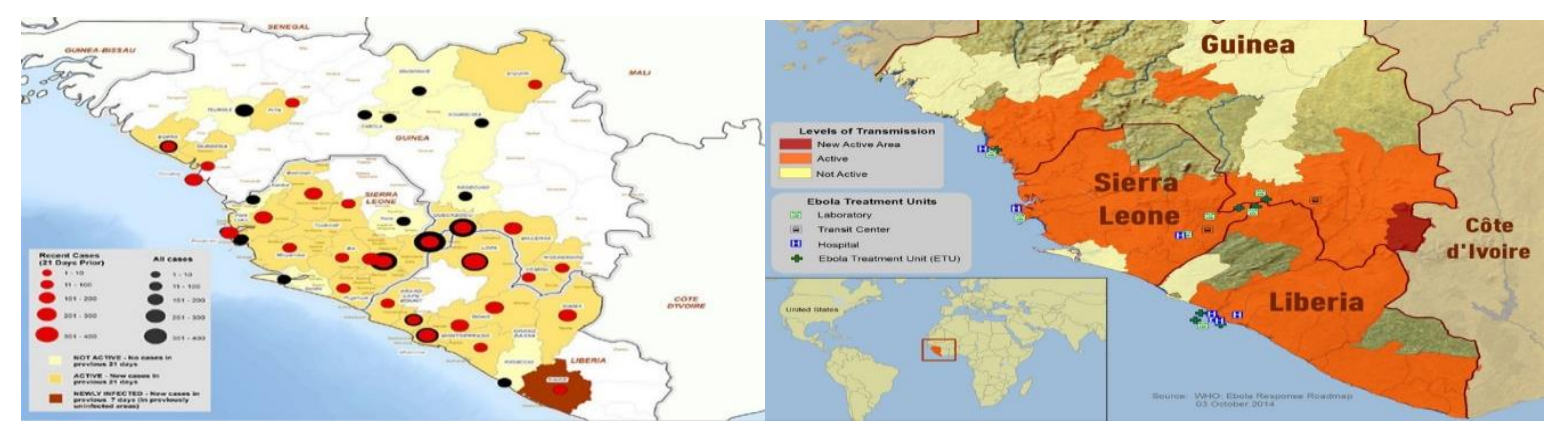

Karta 5. Širenje ebole: najjača prvobitna žarišta (veća regija - dio Gvinejskog primorja) -Sierra Leone, Liberia, Guinea, Senegal - ebola, ime bolesti potječe od rječice Ebole koja teče kroz jedno selo u Kongu, gdje je bolest 1976. prvi put prepoznata u bolnici flamanskih časnih sestara, izvor WHO 

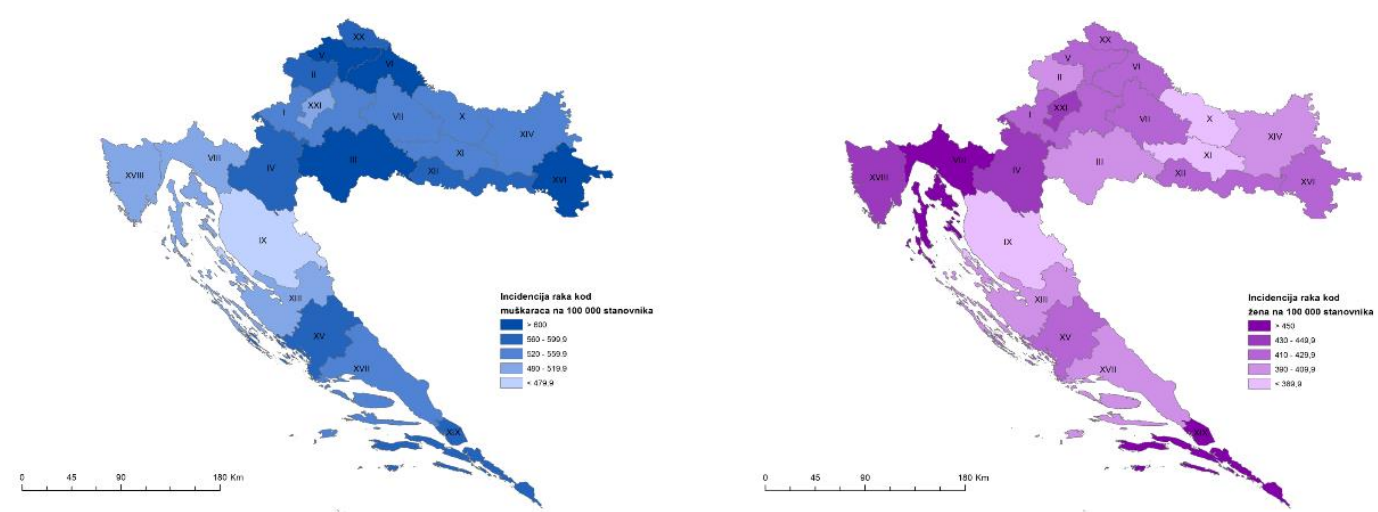

Karte 6 i 7. Incidencija raka prema županijama, dobno standardizirane stope u 2011. godini - na 100000 stanovnika muškarci, karta gore plavo žene, karta dolje, ljubičasto (izvor - Hrvatski zavod za javno zdravstvo, Registar za rak, Incidencija raka u Hrvatskoj 2011., Zagreb 2013., bilten br. 36 (urednik prof. dr. sc. Ariana Znaor, dr. medicine) - Incidencija raka u Hrvatskoj prema županijama - dobno standardizirane stope u 2011. godini)

Namjena ove karte je zoran prikaz rasprostranjenosti raka po županijama Hrvatske. Prva karta pokazuje udio oboljelih muškaraca od raka na 100000 stanovnika. Uočava se da najveći udio oboljelih ima Sisačko-moslavačka, Vukovarsko-srijemska, Varaždinska i Koprivničko-križevačka županija, dok najmanji udio ima Grad Zagreb te Ličkosenjska županija. Karta ispod pokazuje udio oboljelih žena od raka na 100000 stanovnika po županijama Hrvatske. Uočava se da najveći udio oboljelih imaju Primorsko-goranska i Dubrovačkoneretvanska županija. Najmanji udio imaju Virovitičko-podravska, Požeško-slavonska i Ličko-senjska županija. Nadalje se može istraživati uzrok koji može biti u okolišnim okvirima, a također može biti i u dostupnosti zdravstvenih usluga i slično (Lutring, 2010.). Znanstveno-istraživačke karte su uglavnom detaljne izvorne karte koje imaju precizno postavljene ciljeve, metode rada, specifične kartografske modele prilagođene namjeni karte. Temeljna karta je izabrana prema temi. Mjerila su češće velika. Pomažu u istraživanju, ukazuju na promjene, razvoj itd. Mogu je koristiti različite institucije koje se bave razvojem zemalja, te poboljšanjem zdravlja stanovništva. 


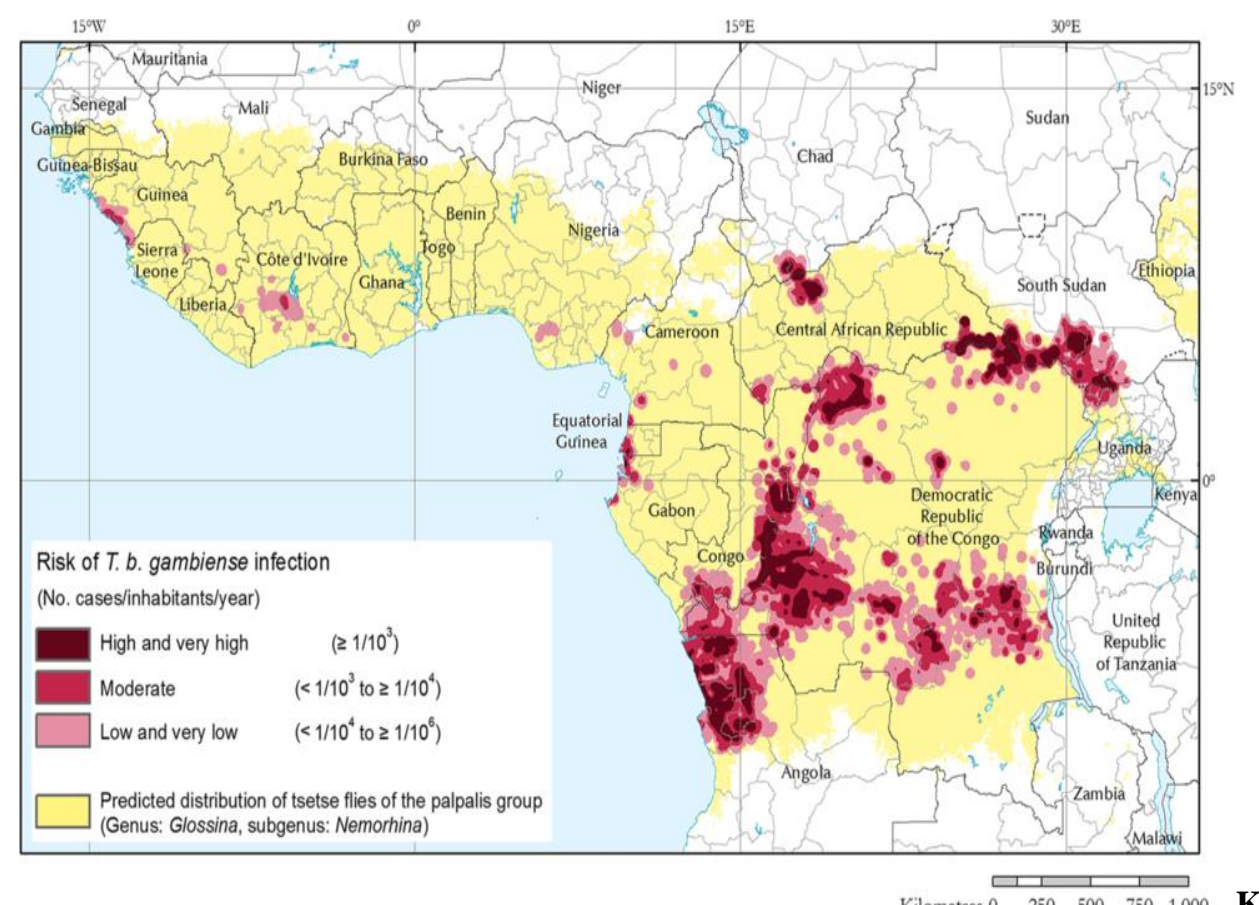

Kilometres $0 \quad 250 \quad 500 \quad 750 \quad 1,000 \quad$ Karta

8. Primjer istraživačke karte - detaljna analiza jednog izdvojenih područja država ekvatorijalne Afrike

Suvremena kartografija omogućava sustavno i pregledno predočavanje brojnih podataka. Počeci mapiranja u SAD-u, važni za razvoj medicinske geografije, potječu od Jacques Maya, koji je napravio projekt mapiranja vektora, parazita i bolesti povezane s prehranom na svjetskoj razini za Američko geografsko društvo u New Yorku. Između 1950. i 1954. izradio je seriju od 17 karata koje su objavljene uz kratko objašnjenje za časopis The Geographic Review. Usto je objavljeno još nekoliko karata, pri čemu je pažnja većine geografa usmjerena na povezivanje rasprostranjenosti bolesti u sponi sa ekološkim i fizičkim okolišem i kulturnim obilježjima. Nakon nekoliko godina Rodenwaldt i Jusatz (1952. - 1961.) izdali su mnogo iscrpniji, od tri dijela sastavljen Atlas svijeta epidemijskih bolesti (Welt Seuchen Atlas, njem. ili engl. World Atlas of Epidemic Disease), taj atlas se sastoji od globalnih i regionalnih karata, s posebnim naglaskom na prostor Europe, te je popraćen komentarima o bolestima.

\section{MEDICINSKA GEOLOGIJA}

Medicinska geologija je suvremena znanstvena disciplina $\mathrm{u}$ progresiji koja se bavi proučavanjem utjecaja geoloških materijala i procesa na zdravlje ljudi, kao i na životinje i biljke, pri čemu se uočavaju dobri i mogući opasni utjecaji.

Kada govorimo o okolišu u sklopu medicinske geologije „uže gledajući“ 
ovdje se uzrok zdravstvenog problema istražuje u geološkim materijalima (sastojcima), procesima, primjeri su količina različitih elemenata $\mathrm{u}$ tragovima $\mathrm{u}$ vodi(stijenama, tlu) ili pojavi vulkanske prašine, plina i slično. Od bitnog značaja je prisutnost ili odsutnost određenih sastojaka u okruženju koje može biti uzrok oboljenja. Ljudsko tijelo dobro je prilagođeno za borbu sa životom na površini Zemlje, ali postoje situacije kada u okolišu postoji nedostatak koji utječe na zdravlje. Danas se to može istraživati. Pri tome ključnu ulogu ima prirodna pojava pojedinih elemenata ali nezanemariv je kvazi-prirodni, odnosno, antropogeni izvori u okoliš. Zaštita na radu uvijek od zdravstvenih stručnjaka traži da različitim metodama istraživanja postavljaju granice i standarde radi smanjenja izlaganja radnika opasnim uvjetima u različitim industrijskim zanimanjima. Zemljina kora građena je od stijena čiji se površinski dio pod utjecajem atmosferskih pojava pretvara u tlo, a u stijenama i tlu možemo naći elemente $u$ tragovima čija je koncentracija mala ali presudna za naše zdravlje. Trošenje i s tim u vezi mijenjanje matične stijene tijekom vremena utječe na stvaranje tla, također, i na floru i faunu. Kemijsko trošenje stijena djeluje na sastav vode koja teče kroz stijene. Nedovoljna ili prekomjerna količina pojedinih elemenata ugrožava naše zdravlje. Nedostatak joda dovodi do bolesti guše, a nedostatak fluora povećava pojavu karijesa zubi, nedostatak cinka otežava iscjeljivanje rana itd.

\section{Primjeri organskih ili anorganskih sastavnica okoliša povezanih $\mathbf{S}$}

bolestima. Čestica praha se sastoji od biološki izvedene tvari životinjskog i mikrobiološkog porijekla i sadrže gljivice, odnosno, bakterije. Anorganski oblici čestica - mogu biti minerali kao što su azbest ili silicij ili komplet minerala (kvarc, piroksen i slično) koji se mogu naći u geološkim naslagama, vulkanskom pepelu ili sedimentnim stijenama. Azbest se ubraja u minerale koji dobro provode toplinu i otporni su na koroziju, te se općenito koristio za izolaciju, građevinski materijal i proizvode poput kočnica (radi trenja). Minerali azbesta se prirodno mogu naći u okolišu. Ipak, uočeno je njegovo štetno djelovanje koje može biti kancerogeno, te se isključuje iz upotrebe. Jedan od primjera minerala azbesta je antigorit koji je nađen u Novoj Kaledoniji $\mathrm{u}$ izvornim serpentinskim stijenama. Ta stijena se koristi u cestogradnji a povezana je a malignim mesothelioma u lokalnim populacijama. Prisutnost ili odsutnost nekih minerala može biti povezana $\mathrm{s}$ bolestima. Na primjer, arsen može biti povišen $u$ geotermalnim vodama $i$ 
antropogenim aktivnostima kao što je rudarstvo. Kemijski elementi koji su bitni za naše zdravlje asimiliraju se u naše tijelo putem prehrane i zraka. Ima ih u biljkama, vodi i tlu. I ljudi i životinje su tražili mineralne naslage gdje ima soli kao dodatak prehrani. Morska riba ima visoki postotak joda, a njegov nedostatak dovodi do povećanja tiroidne žlijezde i bolesti poznate kao guša. Problem je povišena ili smanjena razina radi iscrpljivanja bilo prirodnim bilo antropogenim putem. Primjer medicinske geologije i dobrog djelovanja geologa je pojava arsena $u$ pitkoj vodi u Bangladeshu, koji je otkriven pri geološkim radovima. Anorganski arsen je moćan toksin koji uzrokuje opsežne zdravstvene probleme. Izloženost arsenu utječe i na povećanu mogućnost raka pluća, bolesti bronhija i TBC-a kao i na smanjenje plućne funkcije, povećanu osjetljivost na niže respiratorne infekcije. Utječe i na oštećenje kože, hipertenziju, šećernu bolest, povećanu smrtnost dojenčadi i odrasli (Warren, 2016).

$B E N$, balkanska endemska nefropatija, bolest je bubrega u nekim dijelovima dolina pritoka rijeke Dunav, na prostoru Rumunjske, Bugarske i Srbije, koja se povezuje sa zalihama ugljena nastalih $u$ doba pliocena (prije 5.3 do 1.6 milijuna godina). I brojni drugi primjeri (Boulos, Le Blond, 2016).
Elementi u tragovima su od posebnog interesa. Riječ je o nizu elemenata kojih ima malo u prirodi. Medicinska geologija je zauzela stav da višak ili manjak tih elemenata može dovesti do zdravstvenih problema. Nedostatak selena, flora i molibdena kod ljudi dovodi do jedne kritične granice opasne po zdravlje tzv. „terapijski raspon“, nedostatak selena povećava rizik od smrtnosti, slabi imunološki sustav i kognitivne sposobnosti. Može se nadomjestiti odgovarajućom prehranom. Mobilnost i distribucija ovih elemenata $u$ okolišu je važna i ovisna o promjenama u okolišu. U lateritnim tlima tropa ima metala - kobalta, kroma, nikla, mangana mnogu te se mogu ekstraktirati u rudarstvo, pri čemu je uvijek rizik na poslu. Elementi u tragovima su kalcij, krom, željezo, jod, bakar, mangan, cink, kobalt, molibden, selen, kositar, vanadij, flour, silicij, nikal, arsen, kadmij, magnezij, fosfor, kalij i natrij.

Za demonstraciju medicinske geologije vjerodostojni su navodi da riječ ,kobalt“ i „nikal““ na njemačkom znače zao i nitkov. (to su zli duhovi u rudama koji uzrokuju štetu). U 17. stoljeću je u njemačkim se crkvama molilo posebno za rudare. Kod prehrambenih usjeva $\mathrm{i}$ elemenata $\mathrm{u}$ tragovima njihova koncentracija će na primjer u mahunarki ovisiti o vrsti tla, dok 
zrna žitarica su manje pod utjecajem koncentracije elemenata u tragovima u tlu. Iznimka od ovoga su selen i cink kojih ima u žitaricama. Ciljevi medicinske geologije - prepoznati i pronaći uzrok bolesti, radi intervencije i prevencije - potrebna je temeljita istraga problema.

Prirodni ljekoviti činitelji nalaze se u izobilju u Zemljinoj kori. Primjer su toga i slane sobe u kojima se danas liječe pretežno dišni organi, što se naziva haloterapija (grč. halo, znači sol). Halo terapija se temelji na ljekovitom učinku kamene soli koje je davno uočeno $u$ rudnicima kamene soli. Mogućnosti današnjeg vremena koriste lijepo uređene halokomore izrađene od prirodne kamene soli. U prostorijama ljekovita mikroklima služi prirodnom liječenju.

Boravkom u slanoj sobi udišu se najfinije mikro-čestice kamene soli, aerosol, odnosno čisti natrijev klorid bez aditiva, što pozitivno utječe na smanjenje upala $\mathrm{i}$ pomaže u boljem radu pluća. Aerosol sadrži cijelu paletu minerala. U uvjetima današnje urbanizacije, energetike i drugih tekovina suvremene civilizacije udišemo mnogo nepoželjnih čestica, te ovaj oblik prirodnog liječenja između ostalog možemo zahvaliti unutrašnjosti Zemljine kore i njenog mineralnog bogatstva.

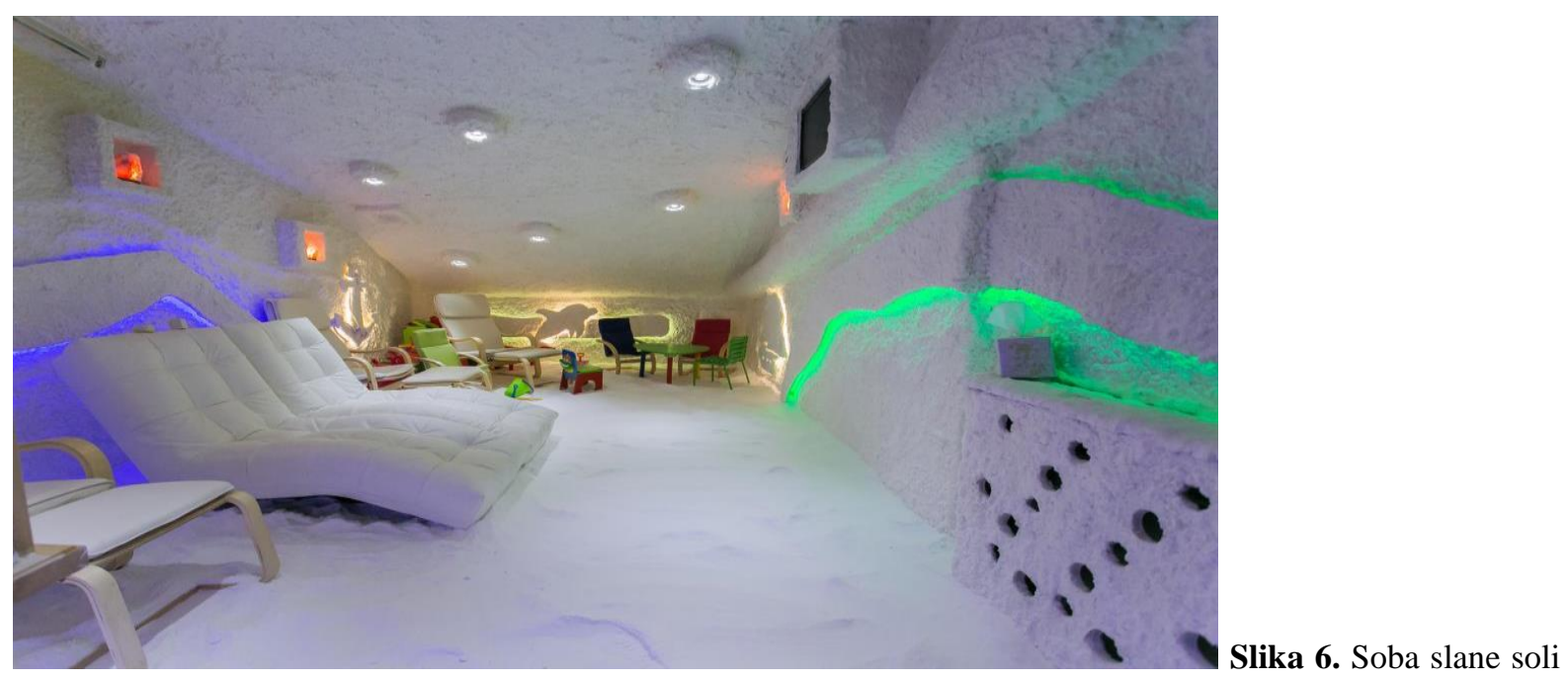

izrađena je od kamene soli. IZVOR : HALOTERAPIJA - Slana soba: koje sve bolesti i tegobe liječi i kome se preporučuje (Modus vivendi /int. ŽIVIM.hr)

\section{Primjeri fizičke i socijalne geografije i medicinska geografija}


Klimatske promjene utjecale su na migracije nekih komaraca prijenosnika bolesti iz Afrike. Kao primjer navodimo komarca - Chikungunya (CHIKV) te Aedes albopictus (Azijski tigrasti komarac) koji su prenijeli viruse u Europu koji su uzročnici oboljenja. Chikungunya, tropski komarac, smatra se putovanjem prenesen $\mathrm{u}$ Europu, prijenosnik je bolesti čije je prvo europsko izbijanje stiglo u sjevernu Italiju 2007. Nakon toga je prenesen $u$ jugoistočnu Francusku 2010. Obje pojave bolesti dogodile su se nakon ulaska komarca Chikungunya, te još jednog Aedes albopictus (Azijski tigrasti komarac) u Europu. Istraživanje je provedeno sa ciljem da se ustanovi da li ove pojave ukazuju na početak trenda ili su samo trenutačan, sporadičan događaj. Potrebno je ispitati faktore koji utječu na potencijalni prijenos Chikungunya $u$ Europu. Klimatske promjene sada i u budućnosti bitna je polazna točka za takve analize. Klimatski preduvjet za dolazak navedenog komarca je određena pomoću bioklimatskih čimbenika koji utječu na vektore i patogene(zarazu). Istražen je i komarac Aedes Albopictus. Općenito se smatra da je najveći rizik u Europi tijekom 21. stoljeća od prijenosnika opasnog virusa Francusku, sjevernu Italiju i Panonsku nizinu(srednje-istočnu Europu). Kako bi se spremno dočekalo eventualno daljnje širenje, moraju se identificirati područja sa pojačanom opasnošću radi pravovremenih provođenja određenih javno-zdravstvenih mjera, može se provoditi nadzor i kontrola vektora. Usput rečeno treba voditi računa da li je klima jedini uzročnik (Fisher, Thomas, Suk, Sudre, Hess, Tjaden, Beierkuhnlein, Semenza 2013).

\section{Što je bioprognoza vremena?}

Od godine 1999. Svjetska meteorološka organizacija posvetila je posebnu pažnju utjecaju vremena i klime na ljudsko zdravlje. Mnogi liječnici su u svojoj praksi zapazili utjecaj vremena na učestaliju pojavu akutne faze raznih bolesti ili na njihovo pogoršanje, pa uvažavaju taj utjecaj i vode računa o njemu. To je interesantno $u$ svjetlu današnjeg trenda promjena globalne klime, čiji su učinci posljednjih godina dosta naglašeni. $\mathrm{S}$ tim $\mathrm{u}$ vezi je WMO zajedno sa Svjetskom zdravstvenom organizacijom - WHO $\mathrm{u}$ svojim proučavanjima utvrdila sponu vrijeme - klima - zdravlje naglašavajući bitne spoznaje o kojima čovječanstvo danas mora voditi računa kako bi se sutra smanjili mogući negativni učinci vremena i klime na zdravlje. Razvila se grana primijenjene meteorologije

biometeorologija koja proučava utjecaj vremena na žive organizme, biljke, životinje i ljude. Utjecajem vremena na 
ljude bavi se humana biometeorologija. $\mathrm{Na}$ osnovi toga razvila se bioprognoza vremena. U njoj se, uz opis meteorološke situacije, najavljuje dolazak onih vremenskih prilika koje mogu slijedećeg dana ili slijedećih dana više ili manje nepovoljno djelovati na ljudsko zdravlje, $s$ ciljem organiziranja preventivnih mjera. Bivša zapadna Njemačka prva je nakon Drugoga svjetskog rata počela izradu svakodnevnih biometeoroloških prognoza koje su se dostavljale bolesnicima, zdravstvenim centrima i privatnim liječnicima. Danas ih rade mnoge zemlje u svijetu. U Zagrebu je prva bioprognoza, u sadašnjem obliku, objavljena 3. ožujka 2003. godine (Zaninović Gaćeša, 2017).

\section{Desezonalitet mortaliteta}

Desezonalitet mortaliteta primjer je utjecaja klime, povezan sa smjenom godišnjih doba, na mortalitet. Naime, sezonalitet mortaliteta već je uočen prije 2 500 godina, ljudi su znali da neki uzročnici smrtnosti ljude najčešće pogađaju $u$ jednom godišnjem dobu, a drugi u drugom. Prije 100 godina znanstvenici u SAD-u su potvrdili da se ljeti umire od malarije, žute groznice, kolere, tifusa, gastroenteroloških bolesti i tuberkuloze, a zimi od gripe, moždanog udara i drugih bolesti povezanih sa hladnoćom. Jedan od najvećih autoriteta koji je 25 godina proučavao sezonalitet mortaliteta je Japanac Masako-SakamotoMomiyama, znanstvenik sa Meteorološkog instituta u Tokiju. Proučavao je bolesti u različitim područjima i klimama, dobnom sastavu, kulturnim i socioekonomskim sredinama, rasama, etničkim skupinama. Došao je do zaključka da je mortalitet $u$ većini zemalja bimodalan, tj. ima zimski i ljetni vrhunac (max). S gospodarskim razvojem ljetni max postepeno nestaje, što znači da mortalitet postaje učestaliji zimi. To je posljedica standarda, tekovina kao što su hladnjaci, klima uređaji, zimi centralno grijanje itd.

\section{Urbana geografija - projekt zdravi grad}

Urbana geografija, znanstveno područje koje se bavi proučavanjem gradskih naselja vrši istraživanja veze između zdravlja i ljudi. Ne samo dostupnost zdravstvenim uslugama, koja je osjetno veća u urbanim sredinama, nego u ruralnim, poseban ekološki utjecaj gradskih sredina (Fischer, Suk, Sudre 2014), već i novi trendovi s projektima kao što je projekt zdravih gradova, a u novije vrijeme još aktualniji projekt pametnih gradova (Smart cities), koji suvremenom internetskom tehnologijom nadopunjuje projekt zdravih gradova i pomaže u ciljevima. Projekt zdravih gradova pokrenula je Svjetska zdravstvena organizacija 1987. Kao dio 
ovog globalnog programa oko 90 gradova su članice WHO mreže zdravih gradova i još 30 nacionalnih mreža zdravih gradova u Europskoj regiji, sveukupno ima više od 1400 gradova i mjesta kao članova. WHO definira „Zdravi grad“ kao onaj koji neprestano stvara i poboljšava one fizičke i društvene okoline $i$ širi one resurse zajednice, koji omogućuju ljudima da međusobno podržavaju jedni druge u obavljanju svih funkcija života i u razvoju do maksimalnih potencijala. Cilj je promicanje sveobuhvatne lokalne strategije za zaštitu zdravlja, stavljanje zdravstva visoko na društvenom, ekonomskom i političkom planu prioriteta gradskih vlasti, također, cilj je uklanjanje nejednakosti u zdravlju urbanog stanovništva, te aktivno uključivanje građana u projekt (Kamel Boulos,

Al-Shorbaji, 2014).

\begin{tabular}{|l|l|l|l|}
\hline Rank & City & Average life & Happiness level \\
\hline 1 & Amsterdam & 81.2 & 7.44 \\
\hline 2 & Sydney & 82.1 & 7.22 \\
\hline 3 & Vienna & 81 & 7.29 \\
\hline 4 & Stockholm & 81.8 & 7.35 \\
\hline 5 & Copenhagen & 79.8 & 7.64 \\
\hline 6 & Helsinki & 80.4 & 7.80 \\
\hline 7 & Fukuoka & 83.2 & 5.87 \\
\hline 9 & Barcelona & 82.2 & 6.40 \\
\hline
\end{tabular}




\begin{tabular}{|l|l|l|l|}
\hline 10 & Vancouver & 81.70 & 7.23 \\
\hline 11 & Melbourne & 82.10 & 7.22 \\
\hline
\end{tabular}

Tabela 1. Deset najzdravijih gradova u 2021. (One Aussie city makes the top 10 once again; by Nikolina Ilic) Izvor: https://www.menshealth.com.au > Health

Nekoliko zanimljivosti

Povjesničari su uočili da su epidemije i pandemije bolesti predstavljale važan i ponekad presudan čimbenik u stvaranju povijesti jer su usmjeravale tijek povijesnih i gospodarskih događanja kao i kretanje stanovništva. Postoji podatak da je Herodot, grčki povjesničar uočio da je nekakva zaraza spriječila asirskog kralja Sanheriba da ne napadne Izrael u 7. st. pr. Krista. Kuga koja je harala sredinom 14. stoljeća, plućna po obliku divljala je po Europi i ponegdje smanjila stanovništvo za jednu trećinu, što je izazvalo nestašicu radne snage, pad prihoda zemljoposjednika, pogađala je gradove, pogotovo u vrućim ljetnim danima, kada su opustjeli poticane su migracije iz obližnjih sela te se mijenjala struktura stanovništva (Green, 1993).

Prva karantena u svijetu u Dubrovniku. Kuga je zahvatila i Dubrovnik te je godine 1377. grad Dubrovnik donio zaključke o karanteni tj. zaštiti od unošenja kuge. U Veneciji je karantena uvedena 80-ak godina poslije zato možemo zaključiti da je dubrovačka karantena možda prva te vrste u svijetu i predstavlja temelj za brojne postupke zaštite od zaraznih bolesti koji su se poslije toga razvijali na području Hrvatske. Prema tom zakonu svi stanovnici iz Dubrovnika i stranci koji dolaze iz zaraženih krajeva moraju biti izolirani mjesec dana u Cavtatu ili na otoku Mrkanu. Donesena je i odluka i o kontroliranoj izolaciji brodova kao postupku zaštite od unošenja kuge s mora. Dakle, niz mjera je proveden zbog bolesti koja je utjecala na mortalitet, migracije, razvoj naselja i slično (Bačić, 1990).

Dostupnost antibiotika i cjepiva. Nakon drugog svjetskog rata antibiotici i drugi lijekovi postaju prvi puta širom dostupni, te je tako stopa smrtnosti djece pala sa od oko 200 na 1000, na oko 90 na 1000, životni vijek se produljio u mnogim državama na 55 godina, što je rezultiralo rastom svjetskog stanovništva. Također je uočeno da je u gradskom sredinama gdje je veća dostupnost zdravstvenih usluga taj trend izraženiji nego u ruralnim krajevima. Zdravstveni djelatnici došli su do spoznaje kada bi slabo razvijene zemlje mogle 
slijediti model razvijenih te bi tako smanjile natalitet i produljile životni vijek. Uočeno je da pad mortaliteta može biti ugrožen radi društvene i gospodarske krize što se dogodilo u Rusiji koja je nakon raspada sovjetskog sustava 1990-ih povećala mortalitet zbog kardiovaskularnih bolesti uglavnom radi alkoholizma. Uzroci širenja zaraznih bolesti mogu biti prouzočeni nemogućnosti proizvodnje i dostave medicinskih proizvoda, neplaćanje medicinskog osoblja i slično. Jedno istraživanje provedeno u pokrajini Taiz u Južnom Jemenu 2010. godine imalo je cilj ukazati na povezanost učestalosti i razvoju više ili manje bolesti malarije djece od 6 mjeseci do deset godina starosti sa dostupnošću cjepiva za ovu tešku zaraznu bolesti. Analizirala se mreža cesta i transportni sustav, te je uočeno da postoji snažna korelacija između udaljenosti, trajanja vožnje i pristupa zdravstvenim uslugama (Al-Taiar, Clark, Longenecker, Whitty, 2010).

GIS tehnologije. Za planiranje efikasnije primarne zdravstvene zaštite preporuča se korištenje GIS tehnologije. GIS, geografski informacijski sustav posebnim metodama prikuplja, pohranjuje, obrađuje i kreira nove informacije i izlazne proizvode. Razvija se od 1970. godine i koristi gotovo u svim granama ljudske djelatnosti, u medicini je također izuzetno prisutan. Najsuvremenijim digitalnim metodama izrađuje između ostalog tematske karte užeg i šireg prostora. Sada u doba pandemije koronavirusa posebno je važan jer stalno ažurira karte, izrađuje karte i za mala područja omogućujući zdravstvenim djelatnicima lakše uočavanje smjerova pojačanja i slabljenja pandemije. Najnovija dostignuća geografskog informacijskog sustava (GIS) daju veću mogućnost $u$ planiranju dostupnosti zdravstvenih usluga i u manje pristupačnim područjima (Lukić, 2003).

\section{ZAKLJUČAK}

Medicinska geografija suvremena je znanstvena disciplina, starih korijenova, koja primjenjuje metodologiju geografije, koristi tehnike i koncepte svih disciplina geografije pri istraživanju zdravstvenih problema u prostoru. Ujedno proučava $\mathrm{i}$ geografsku rasprostranjenost oboljenja, te aktualne novonastale zdravstvene probleme i bolesti. U sklopu geografije slijedi se stoljetni cilj - povezivanje svih fenomena sa naglaskom na prostor $\mathrm{s}$ namjerom da razumiju prirodu mjesta $\mathrm{i}$ objašnjavanje rasprostranjenosti različitih zdravstvenih fenomena u prostoru. Na taj način geografi su počeli razmatrati vezu prostor - geografski okoliš - zdravlje. Ipak korijeni joj sežu u daleku povijest. 
Najpoznatiji dokaz je citat Hipokrata, 400 godina prije Krista $\mathrm{O}$ zraku, vodama i mjestima gdje Hipokrat ukazuje na povezanost okoliša i kulturnih običaja za zdravljem ljudi. Svijest o ekološkoj sponi bolesti i zdravlja kontinuirano se pojavljivala stoljećima sve do pojave prvih teorija u drugoj polovici 19. stoljeća. Liječnici iz 18. i 19. stoljeća prvi su upotrijebili pojam „medicinska geografija“ i nastojali u mnogim svojim djelima opisati i organizirati mnoštvo novih informacija u kojima se uočava povezanost bolesti, kultura i okoliša, te su tako nastavljali holističku Hipokratovu tradiciju. Ovdje izdvajamo dva znanstvenika koji su utemeljili medicinsku geografiju - J. M. May i L. L. Finke. Godine 1789. Finke je prvi predložio studij medicinske geografije svijeta. Tada je namjeravao „stvoriti“ geografsko-povijesno-sociološki““ esej i tiskane karte koje bi bile prve karte svjetskih bolesti. Tijekom 19. stoljeća pojavljuju se prve geografske karte sa medicinskim sadržajem. Jedna od najpoznatijih je karata koju je u 19 . stoljeću u Londonu izradio dr. Snow za vrijeme epidemije kolere. Suvremeni značaj i razvoj medicinske geografije započinje iza 1950. godine. Najistaknutiji znanstvenik je francuski kirurg Jacques Meyer May, kojeg se zato simbolički naziva - „otac“ suvremene medicinske geografije. Radno iskustvo kirurga je između ostalog stjecao $\mathrm{u}$ tropskom prostoru Indokine te uočavao utjecaj tropske klime na bolesti i liječenje. May smatra da je medicinska geografija proučavanje o vezi između patoloških faktora koji je mogu zvati ,patogeni“ i geografskih faktora koje je dr. May nazvao, „geogeni“. U radu je objašnjeno značenje kartiranja (mapiranja) bolesti pri čemu se izdvajaju opće tematske karte većih područja i rasprostranjenost bolesti i slično, te ujedno precizne istraživačke karte malih prostora rađenje metodama GIS-a koje detaljno istražuju probleme pojedinih manjih prostora od dostupnosti lijekovima i zdravstvenim ustanovama, širenje bolesti i brojnih drugih zdravstvenih sadržaja. Karte sa medicinskim sadržajem su geomedicinske karte. Nadalje u radu se ukazuje na interdisciplinarnost medicinske geografije. U gotovo svim geografskim disciplinama izdvajaju se sadržaji i teme koje koreliraju sa zdravljem. Primjer je utjecaj klime na zdravlje, posebno utjecaj globalno zatopljenja i migracije čimbenika zaraze. Zatim područje bioprognoze vremena, gdje su WMO i WHO u suradnji objedinile vrijeme, klimu i zdravlje. Medicinska geologija zasebno je područje, vezano također na geografiju te medicinsku geografije koje ukazuje na utjecaje koji 
proizlaze iz Zemljine kore i stijena. Medicinska geografija je novo područje koje koristi najnovije metodologiju, GIS, razne teorije, pristupe, ima brojne interese

\section{LITERATURA}

1. Al-Taiar, A., Clark, A. Longenecker, J, Whitty, C. 2010. Physical accessibility and utilization of health services in Yemen International Journal of Health Geographic, 8.

2. Bačić, J. 1990. Nekad u Dubrovniku, Dubrovnik zdravi grad. Dubrovnik. 3. Kamel Boulos, M. Al-Shorbaji, N. On the Internet of Things, smart cities and the WHO Healthy Cities. 2014. International Journal of Health Geographics, 13.

4. Brown, T., Moon, G. 2004. From Siam to New York : Jacques May and the „foundation“ of medical geography. ELSEVIER. Journal of Historical geography, 30: 747-763.

5. Finke, L. L. 2001. Medical Geography by Andrea Nuernberger. Santa Barbara.

6. Green, V. 1993. Ludilo kraljeva. Naklada Ljevak. Zagreb.

8. Lukić, A. 2003. Digitalna karta - ususret geografiji budućnosti? Edupoint. Časopis o primjeni informacijskih u suradnji sa zdravstvenim djelatnicima i sudjeluje u brojnim projektima.

6. 7. Fisher, D., Thomas, S. M, Suk, J. E., Sudre B., Hess A., Tjaden N. B., Beierkuhnlein, C., Semenza J. C. Climate change effects on Chikungunya transmission in Europe: geospatial analysis of vector's climatic suitability and virus' temperature requirements. 2013. International Journal of Health Geographics, 12.

tehnologija u obrazovanju, 3.

9. Meade, M. S., Earickson, R. J. 2005. Medical geography. The Guilford Press, New York - London.

10. Misra, R. P. Geography of Health. 2007. A Treatise on Geography of Life and Death in India.

11. Lutring, V. 2010. Tematsko kartiranje pomoću SVG-a na primjeru detaljne klasifikacije umrlih prema uzroku smrti po županijama. Diplomski rad. Geodetski fakultet. Zagreb.

12. Zaninović Gaćeša, K. 2017. Možemo li biti bolesni od vremena, /www. mirovina.hr / zdravlje 


\section{SUMMARY}

\section{MEDICAL GEOGRAPHY}

Medical geography is a modern scientific discipline that applies the methodology of geography, and uses techniques and concepts of all disciplines of geography in researching health problems in space, and studies the geographical distribution of diseases and current emerging health problems and diseases. Within geography, a century-old goal is pursued - to consider the connection SPACE - GEOGRAPHICAL ENVIRONMENT HEALTH Its roots go back to distant history. The most famous evidence is the quote from Hippocrates, $400 \mathrm{BC}$ On air, water and places where Hippocrates points to the connection between the environment and cultural customs for human health. Physicians of the 18th and 19th centuries were the first to use the term "medical geography" and sought to describe and organize many new pieces of information in their work that linked disease, culture, and the environment, thus continuing the holistic Hippocratic tradition. Here we highlight prominent scientists who founded the medical geography of Finke, 18th century, and Jacques Mayer May, Leonhard Ludwig Finke, born in Germany, is one of the pioneers of medical geography. According to Finke's definition, medical geography should cover the entire inhabited world (ecumenism). As a physician, he hoped that geography would be able to offer explanations of cause and effect and help better understand the disease. In 1789 he was the first to propose the study of the medical geography of the world. At that time, he intended to "create" a geographical-historical-sociological "essay" and printed maps that would be the first maps of world diseases. During the $19^{\text {th }}$ century, mapping of diseases became more frequent. Medical geography, however, is a modern science, beginning in the 1950s. The application of geography methodology to the study of health, science is advancing using a variety of theories, approaches, interests, and methodologies. He also participates in numerous projects and creates them. The founder of the "father" of modern medical geography is Jacques Meyer May (1896-1976), a French surgeon. He believes that medical geography is the study of the relationship between pathological factors that can be called "pathogens" and geographical factors that Dr. May called "geogens." Mapping (mapping) of health problems, ie entering medical data on geographical maps, is a regular occurrence today. According to the thematic area, maps with medical content are geomedical maps. Medical geology is a modern scientific discipline in progression that deals with the study of the impact of geological materials and processes on human health, as well as on animals and plants, with good and possible dangerous influences. Trace elements, important for our health, originate directly or indirectly from the Earth's crust. Biometeorology refers to the link between weather and climate health.

Key words: medical geography, space-health, L. L. Finke, disease mapping, J. M. May, pathogens - geogens. 